\title{
Fen Lisesi Kimya Öğretmenlerinden Bir Yansıtma: Güncellenen Kimya Öğretim Programı ile İlgili Görüşler*
}

\author{
A Reflection from Chemistry Teachers of Science High Schools: Views \\ About the Revised Chemistry Curriculum
}

\begin{abstract}
DOI $=10.17556 /$ jef.36724
Sevil AKAYGÜN*, Rıdvan ELMAS ${ }^{* * *}$, Hüseyin $\mathrm{KARA}^{* * * *}$, Faik Özgür
KARATAŞ $^{* * * * *}$, Gözde YILDIRIM

\section{Özet}

Öğretim programlarının uygulanmasında öğretmenlerin programa ilişkin görüş ve inanışları etkilidir. Bu nedenle kimya öğretmenlerinin öğretim programları hakkındaki görüşlerinin belirlenmesi önem taşımaktadır. Bu çalışmanın amacı, fen liselerinde görevli kimya öğretmenlerinin güncellenen kimya dersi öğretim programı hakkındaki görüşlerinin belirlenmesidir. $\mathrm{Bu}$ amaç doğrultusunda fen liselerinde görevli 42 kimya öğretmenin öğretim programı hakkındaki görüşleri alınmıştır. Katılımcıların görüş̧leri, açık uçlu sorulardan oluşan, Kimya Öğretim Programı Değerlendirme Anketi (KÖPDA) ile elde edilmiştir. Elde edilen veriler, içerik analizi ile KÖPDA'da yer alan temalar ışığında analiz edilmiştir. Katılımcıların çoğunluğu yürürlükteki güncel programda hem öğretmenin hem öğrencinin yine aktif olduğunu belirtirken, öğrenme etkinlikleri ve ölçme-değerlendirme konularında olumlu ve olumsuz görüşler ifade eden katılımcıların sayısı yaklaşık olarak aynıdır. Ayrıca, öğretmenlerin çoğunluğu programı açık ve anlaşılır bulduklarını, ancak konuların bazı sınıf seviyelerinde daha yoğun verildiğini belirtmişlerdir. Sonuç olarak, öğretmenler, öğretim programlarının okul türlerine uygun olarak farklılaştırılmasına vurgu yapmışlardır.
\end{abstract}

Anahtar kelimeler: Kimya, öğretim programı, fen lisesi, öğretmen görüşü

Abstract

For an effective chemistry education, it is crucial to determine views of the chemistry teachers. This study aims to investigate the views of chemistry teachers

*Bu çalışma, IV. Ulusal Kimya Eğitimi Kongresi’nde (UKEK 2015) sözlü bildiri olarak sunulmuştur.

** Yrd. Doç. Dr., Boğaziçi Üniversitesi,: e-posta: sevil.akaygun@boun.edu.tr

*** Yrd. Doç. Dr. Afyon Kocatepe Üniversitesi, e-posta: relmas@ aku.edu.tr

***** Prof. Dr. Selçuk Üniversitesi, e-posta: huskara@gmail.com

******Yrd. Doç. Dr., Karadeniz Teknik Üniversitesi, e-posta: fokaratas@ktu.edu.tr

******** Yüksek Lisans Öğrencisi, Boğaziçi Üniversitesi, e-posta: gozde.yildirim@boun.edu.tr 
working at science high schools, about the revised chemistry curriculum. Forty-two chemistry teachers participated in the study designed as survey study where the data were collected by a questionnaire with open-ended questions, Chemistry Curriculum Evaluation Questionnaire (CCEQ). The data were analyzed based on the themes existed in CCEQ. The majority of the chemistry teachers reported that both teachers and the students also have an active role in the current curriculum, but their views were fragmented about the learning activities and evaluation parts in the curriculum. The teachers also emphasized the differentiation of chemistry curricula according to the school types.

Key words: Chemsitry, curricula, science high school, teachers' views

\section{Giriş}

Ülkemizde program geliştirme çalışmaları, cumhuriyetin ilanının hemen ardından 3 Mart 1924'de ilan edilen Tevhid-i Tedrisat Kanunu ile eğitim kurumlarının tek çatı altında toplanması (Varış, 1996) ve John Dewey'in aynı yıl yayınlanan raporu ile başlamıştır (Ayas, 2013).

1928'de Latin harflerinin kabulü ile batının etkileri öğretim programlarına da yansımıştır. $\mathrm{Bu}$ etkilenme dört dönemde görülmektedir (Ünal, Coştu \& Karataş, 2004; Ayas, 2013). Birinci Etkilenme Dönemi (1928-1940), 1930'larda devam eden çalışmalar sonucunda 1930 ve 1938 yıllarında ilk olarak lise kimya programlarının yürürlüğe girdiği görülmektedir (Milli Eğitim Bakanlığı [MEB], 2007). İkinci Etkilenme Dönemi (1940-1960), 1950'li yılların sonlarından itibaren ortaöğretimde fen ve matematik öğretiminde reform çalışmaları başlatılmış (Turgut, 1990), 1953-1954 yıllarında 'örnek program geliştirme' çalışmaları ağırlık kazanmıştır (Demirel, 1992). Üçüncü Etkilenme Dönemi'nde (1960-1985) ise daha çok liselere yönelik program geliştirme çalışmalarına yoğunlaşılırken, 'modern programlar' olarak bilinen Amerikan programlarının adaptasyonu yapılmıştır. $\mathrm{Bu}$ dönemde, 1964'de kurulan Ankara Fen Lisesi'nde Modern Kimya (CHEM Study) programı uygulamaya konulmuştur (Ayas, 2013). "CHEM Study"nin uyarlaması olan modern programlar bazı liselerde uygulanırken diğer liselerde 1950'lerin özelliğini taşıyan geleneksel programlar uygulanmıştır. Hemen ardından, 1985-2004 Arası Dönem'de ise eşitliği sağlamak adına tek tür programa geçilmiş, komisyonlar kurularak programlar yeniden oluşturulmuştur. Bu çalışmalarda konu 
ve amaçlar ele alınmış, ancak öğretim yaklaşımına değinilmemiştir. Dördüncü Etkilenme Dönemi'nde (2004 sonras1) ise uzun y1llar öğretim programlarında yaşanmakta olan sorunları ortadan kaldırmayı, çağdaş, bilimsel, eleştirel ve yaratıcı düşünen, çözüm üretebilen, öz güveni yüksek bireyler yetiştirmeyi hedefleyen ve yapılandırmacı öğrenme yaklaşımını temel alan yeni öğretim programları geliştirilmeye başlanmıştır (Açıkgöz, 2003; Ayas, 2013). Buna bağlı olarak 2007 ve 2013'te yeni kimya öğretim programları uygulanmaya başlanmıştır. Şu an yürürlükte olan kimya dersi öğretim programı ise 2013'ten itibaren fen liseleri de dâhil olmak üzere ülkemizde bütün ortaöğretim kurumlarında okutulmaktadır.

Kimya dersi öğretim programlarını tarihsel açıdan değerlendiren bir diğer çalışmada, Aydın (2010), Cumhuriyet dönemi kimya öğretim programlarını esneklik ve uygulamalar açısından karşılaştırmış; 1930'dan 2007'ye kadar incelenen kimya dersi öğretim programlarında esneklik özelliğine uyulmaya çalışıldığını öne sürmüştür. Aykaç vd. (2006) programın esnek olması ile ifade edilmek isteneni programın farklı durumlara kolayca adaptasyonuna ve diğer disiplinlerle etkili bir koordinasyon içerisinde olabilme yeteneğine bağlamışlardır. Programın esnek olmasını gerektiren nedenler ise "(1) ülke okullarındaki çevre ve iklim koşullarının farklı olması, (2) okulun bulunduğu çevrede yaşayan insanlar arasındaki uygarlık düzeyinin farklı olması, (3) öğrenciler arasındaki bireysel ayrılıklar, (4) bilim ve teknikteki son değişiklikler" şeklinde dört maddede gruplandırılmaktadır (Aydın, 2010; Binbaşığlu, 1988). Aydın (2010), hemen hemen tüm programlarda esnekliğe uyulduğunu, ancak, 2007 kimya öğretim programında bu ilkenin daha fazla öne çıktığını ve programın özellikle bireysel farklılıkları daha fazla göz önünde bulundurarak hazırlandığına dikkat çekmektedir.

Pekdağ ve Erol (2013), 1957-2007 yılları arasında yayımlanan 15 kimya dersi öğretim programını, gerekçe, amaç ve içerik yönünden inceledikleri çalışmalarında kimya eğitiminin altı farklı dönemden geçtiğini belirtmişlerdir. Öğretim programlarında yer alan amaç ifadeleri yazılırken genellikle bilişsel alanın üstün tutulduğunu, programların içeriklerinde yer alan kimya bilgi miktarlarının dönemlere göre farklılık gösterdiğini, bazı kimya programlarının 
örneklerle kimyanın öğretimini amaçlarken, bazılarının ise kavramlarla kimyayı öğretme yoluna gittiğini tespit etmişlerdir. Çalık (2016) ise 2013 kimya dersi öğretim programının (MEB, 2013) öğrencilerin bilimsel süreç becerilerini geliştirmeye yönelik olduğunu, bu nedenle ögretmenlerin daha fazla laboratuvar uygulamaları yapmalarının gerekliliğini savunmaktadır. $\mathrm{Bu}$ nedenle de öğretmenlerin yeterli laboratuvar araç-gereçlerine sahip olmalarının önemini ortaya koymakta, ancak laboratuvar araç-gereçleri olsa bile, mevcut sınav sisteminin öğretmenleri araştırmaya-dayalı fen eğitimi yürütmek yerine geleneksel öğretim yöntemlerine yönelttiğini belirtmektedir.

\section{Öğretim Programları Hakkında Ö̆̆retmen Görüşleri}

Uygulanmış olan kimya dersi öğretim programları araştırmacılar tarafından çeşitli yönlerden incelenmiş, bu anlamda hem önceki programların anlaşılması hem de sonraki dönemlerin yapılandırılması anlamında alana katkı sağlamıştır (Aydın, 2008, 2010; Demircioğlu, Aslan \& Yadigaroğlu, 2015; Ercan, 2011; Erdoğan, 2007; Özden, 2007). Bu çalışmaların bir kısmı tarihsel bir anlayışla doküman analizine odaklanırken (Ayas, 2013; Pekdağ \& Erol, 2013; Ünal, Coştu \& Karataş, 2004) bir kısmı da programın paydaşlarını hedef almıştır (Demircioğlu, Aslan \& Yadigaroğlu, 2015; Ercan, 2011). Öğretim programlarının uygulayıcılarından olan öğretmenlerin görüssleri bu anlamda araştırmacıların sıklıkla odağında yer almıştır.

Aydın (2008), 1992-2007 yılları arasında uygulanan kimya dersi öğretim programlarının uygulama sürecini ve gerçekleştirme boyutunda uygunluğunu, programı uygulayan kimya öğretmenlerinin görüşlerine bağlı olarak incelediği çalışmasının sonucunda; kimya öğretmenlerinin \%70'i öğretim programlarının uygulamaya yönelik olarak yetersizliklerinin olduğunu belirtmişlerdir. Ercan (2011) ise kimya öğretmenlerinin 2007 yllından itibaren kademeli olarak yürürlüğe giren kimya dersi öğretim programı hakkındaki görüşlerinin belirlenmesini amaçlayan araştırmasının sonunda; öğretmenlerin ölçme değerlendirme konusunda bazı eksikliklerinin olduğu, içerik kazanımlarının öğretmenlerce büyük oranda anlaşıldığı, 10. sınıf konularının yoğun olduğu gibi sonuçlara ulaşmıştır. Öğretmen 
görüşlerinin alındığı diğer bir çalışmada da Mercan (2014), 2007 y1lında güncellenen Ortaöğretim Kimya Dersi Öğretim Programı'nın içeriği ve kurgusu hakkındaki öğretmen görüşlerini incelediği çalışmasına katılan öğretmenlerin; \%52'sinin kimyanın günlük hayatla ilişkilendirilmesini onayladığını, \%45'inin sarmal konu sıralanışını gereksiz bulduklarını, \%68'inin fizik ve biyoloji konularının kimya içeriğine katılmasını beğenmediklerini ve \%61'inin içeriği öğrencilerinin ihtiyaçlarına göre esnettiklerini ifade ettiğini, belirtmiştir. Elmas'ın (2016) 2013 y1lı öğretim programı ile ilgili olarak 27 kimya öğretmeni ile yaptığı program değerlendirme çalışmasında ise kimya öğretmenlerinin 3 temel alandaki (kimya alan bilgisi, pedagoji bilgisi ve teknoloji bilgisi) durumları belirlenmeye çalışılmıştır. Bu çalışma özellikle kimya alan bilgisinde disiplinler arası sayılabilecek konularda (Enerji, Kimya Her Yerde ve Kimya ve Elektrik) öğretmenlerin daha fazla sorun yaşadıklarını göstermiştir.

Demircioğlu, Aslan ve Yadigaroğlu (2015) güncellenen kimya dersi öğretim programını öğretmen gözüyle değerlendirildiği çalışmalarında öğretim programının öğretmenlere rehberlik edecek açıklamalar içermediği, teknolojiyi bütünleştiremediği, ölçme ve değerlendirme yaklaşımının açık olmadığı, kavramsal açıdan yoğun ve ezbere özendiren bir yapıda olduğu sonucuna ulaşmışlardır. Bu sonuçlara bağlı olarak öğretim programının sadeleştirilmesi gerektiği ve lise türlerine göre farklı programların hazırlanmasının daha uygun olacağı önerilerinde bulunmuşlardır. Benzer şekilde, Seçken ve Kunduz (2014) yaptıkları çalışmada 2007'de yürürlüğe giren kimya dersi öğretim programının uygulamasında karşılaşılan aksaklıkları belirlemek için öğretmen görüşlerine başvurmuş sonra güncellenen kimya dersi öğretim programının bu sorunları ne kadar giderdiğini tartışmışlardır. Öğretmenlerin 9. sınıfa yönelik dile getirdikleri sorunlar; içeriğin öğrencilerin ilgisini çekmemesi, ders süresinin yetersizliği, içeriğin öğrencilerin seviyelerine uygun olmaması, ezbere dayalı konuların çokluğu, öğrencilerin matematiksel ve soyut düşünme yeterliliklerinin zayıflığı şeklinde sıralanmıştır. Öğrencilerin 9. sınıf kimya dersinde en çok zorlandıkları konular arasında temel yasalar ve çözünürlük problemleri ile ezbere yönelik konuların yer aldığ1 aktarılmıştır. Güncellenen kimya dersi öğretim programında zorluk çekilen konuların çoğu için yeterli düzenlemenin yapılmadığı, 
programın sürekli değişmesi nedeniyle öğretmenlerin programa karşı uyum sorunu yaşadıkları iddia edilmiştir.

Alanyazında ulaşılan çalışmalar incelendiğinde, öğretim programlarına yönelik öğretmen görüşlerinin program değerlendirmede kullanılan önemli bir veri olduğu görülmüsstür. Yeni güncellenen kimya dersi öğretim programına yönelik öğretmen görüşlerinin alındığı çalışmalar oldukça sınırlıdır. Ayrıca, bu çalışmalar genel bir çerçevede öğretmen görüşlerine başvurmuştur. Başka bir deyişle, şu ana kadar yapılmış olan çalışmalar, genellikle anadolu liselerinde yürütülmüş olup okul türlerine göre değerlendirme yapan ya da fen dersleri özelinde sadece fen lisesini odağına alan bir çalışmaya rastlanmamıştır. Ancak ülkemizde kuruluş hedefleri farklı olan okul türleri ve öğrenci profilleri olduğu düşünüldüğünde kimya dersi öğretim programına genel bir bakışın yanında özel durumlara da odaklanılması gerekli görülmektedir.

Sonuç olarak, öğretim programları tarihsel süreç içerisinde farklı dönemlerden geçmiş; kimi zaman tüm okullarda tek tür öğretim programı uygulamasına gidilirken kimi zaman ise okul türüne ve öğrenci özelliklerine uygun öğretim programları benimsenmiştir. Günümüzde, yürürlükte olan kimya dersi öğretim programı, okul türüne göre farklılaştırılmadan, fen liseleri de dâhil olmak üzere, tüm liselerde uygulanmaktadır. Kuruluş amacı ve öğrenci profili bakımından diğer liselerden farklılık gösteren fen liselerinde fen dersleri öğretim programlarının nasıl uygulandığı ise önem kazanmaktadır. Öğretim programlarının en etkili değerlendirmesinin ancak programın uygulayıcıları olan öğretmenler tarafindan yapılabileceği noktasından hareketle, çalışmada sadece fen lisesi kimya öğretmenlerinin öğretim programı ile ilgili görüşlerinin alınmasına karar verilmiştir. Yapılan çalışma ile elde edilen bulgular farklı okul türlerinde kimya dersi öğretim programının algılanma ve uygulanmasına yönelik anlamamızın geliştirilmesine ve öğretim programının daha hedefe odaklı tasarlanmasına katkıda bulunacaktır.

$\mathrm{Bu}$ çerçevede çalışmanın amacı ise, diğer lise türlerine göre farklı hedeflere sahip olan ama aynı kimya öğretim programının uygulandığı fen liselerinde görev yapmakta olan kimya öğretmenlerinin 2013 yılında güncellenen ve 2013-2014 eğitim- 
öğretim yılından itibaren kademeli olarak uygulanmaya başlanan kimya dersi öğretim programı hakkındaki deneyim ve görüşlerinin belirlenmesidir. Çalışmanın sadece fen liselerini kapsayacak şekilde fen liselerinde görev yapmakta olan kimya öğretmenleri ile yürütülmüş olmasının nedeni fen liselerinde okuyan öğrencilerin diğer liselerdeki ögrencilere göre farklı bir profil çizmeleri nedeniyle farklı ihtiyaçlara sahip olacaklarının düşünülmesidir. Özetle, fen liselerindeki öğrenciler, fen derslerine daha fazla ilgi duyan ve ileride fen ile ilgili branşlarda meslek sahibi olmayı hedefleyen öğrencilerden oluşmaktadır. Bu noktadan hareketle, fen liselerinde okutulan fen bilimleri (fizik, kimya, biyoloji) derslerinin öğretim programlarının bu programları uygulayan ve fen lisesi öğrencilerinin gereksinimlerini bilen öğretmenler tarafından değerlendirilmesi önem kazanmaktadır. $\mathrm{Bu}$ nedenle çalışmada, fen bilimlerinin bir dalı olan kimya dersi için geliştirilen öğretim programının, fen lisesi öğretmenleri tarafindan değerlendirilmesi alanyazındaki mevcut çalışmaları tamamlayacaktır.

\section{Yöntem}

Fen lisesi kimya öğretmenlerinin güncellenen kimya dersi öğretim programı hakkındaki görüşlerinin belirlenmesi amacıyla tasarlanan bu çalışma nitel bir bakış açısına sahiptir. Öğretmen görüşleri açık-uçlu sorulardan oluşan bir anket yardımıyla belirlenmiştir. Araştırmada fen liselerindeki genel durumu ortaya koyabilmek için Türkiye'nin yedi coğrafi bölgesinde yer alan fen liselerinde görev yapmakta olan kimya öğretmenlerinin 2013'te güncellenen kimya dersi öğretim programı (MEB, 2013) ile ilgili görüşleri alınmıştır.

\section{Örneklem}

$\mathrm{Bu}$ çalışmada amaçlı örnekleme yöntemlerinden tipik durum örneklemesi yöntemi kullanılmıştır. Öncelikle, Türkiye'nin yedi coğrafi bölgesinde yer alan fen liseleri saptanmış, ardından kolaylık örneklemi yöntemi ile tüm fen liselerinden erişilebilir olanlar belirlenmiştir. Daha sonra bu okullarda görev yapmakta olan kimya öğretmenleri ile iletişime geçilmiş ve çalışmaya katılmayı kabul eden öğretmenler ile çalışma yürütülmüştür. Seçilen okullarda görev yapmakta olan öğretmenlerin demografik özellikleri göz önünde 
bulundurularak çeşitlilik olabilecek en üst seviyede tutulmaya çalışılmıştır (Yıldırım \& Şimşek, 2013). Bu şekilde güncellenen program ile ilgili olarak okullardaki ögretmenlerden farklı bilgi ve tecrübeye sahip olanların örnekleme dâhil edilmesine dikkat edilmiştir.

Çalışmada Türkiye'nin yedi coğrafi bölgesinde bulunan fen liselerinde görev yapmakta olan 42 gönüllü kimya öğretmeninden görüş alınmıştır. Öğretmenlerin 8'i yükssek lisans, 2'si ise doktora derecesine sahiptir. Çalışmaya katılan öğretmenlerin bölgelere göre dağılımı ve mesleki tecrübeleri Şekil 1'de verilmektedir. Şekil 1(a)'da görüldüğü gibi bazı bölgelerden sınırlı da olsa her bölgeden katılımcıya ulaşılmıştır. Çalışmaya katılım gönüllülük esaslı olduğu için ulaşılan her öğretmenin görüşü alınamamıştır. Şekil 1(b)'de görüldüğü gibi katılımcılardan biri hariç hepsi en az 10 yıllık mesleki tecrübeye sahiptir.

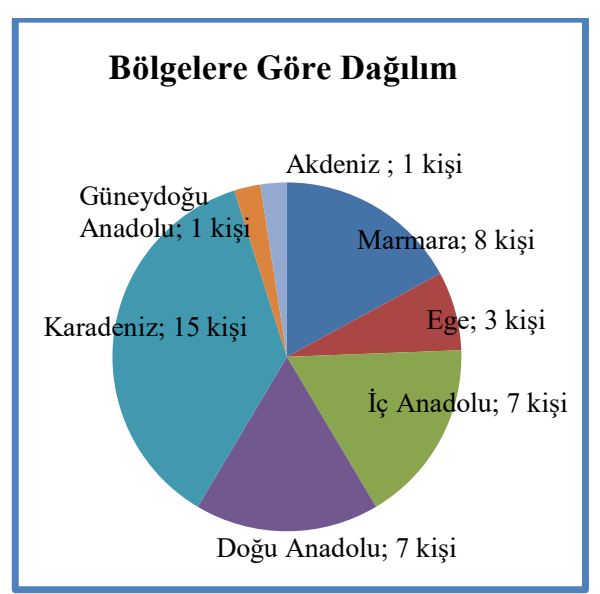

(a)

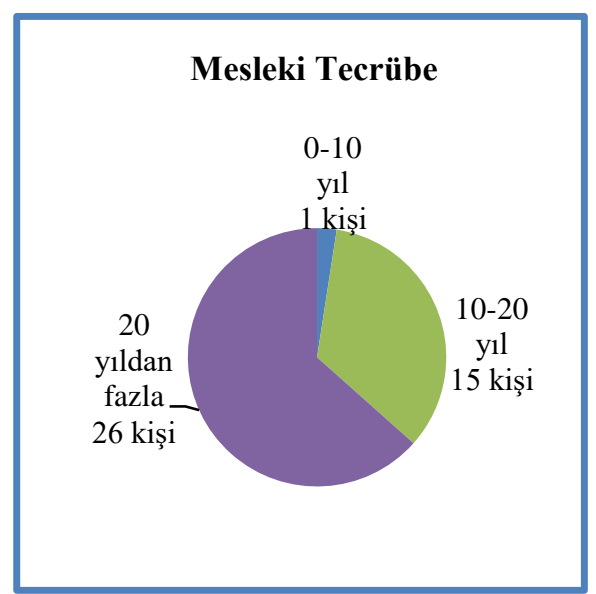

(b)

Şekil 1. Kimya öğretmenlerinin(a) bölgelere göre dağılımı, (b) mesleki tecrübeleri.

\section{Veri Toplama Araçlart}

Fen lisesinde görev yapmakta olan kimya öğretmenlerinin görüşleri, Elmas vd. (2014) tarafından geliştirilen 14 açık-uçlu sorudan oluşan Kimya Öğretim Programı Değerlendirme Anketinin 
(KÖPDA) bu çalışmanın amaçlarına uygun olarak revize edilmesi ile elde edilmiştir. Revizyon işlemi uzman grubu ile yapılan bir seri toplantı sonucunda her bir sorunun üzerinde bire bir tartışılarak yapılan gerekli düzenlemelerin gerçekleştirilmesi ile meydana gelmiştir.

KÖPDA, ögretim programının yapısı, ögretim programının kabulü, öğretim programının içerĭgi ile ilgili fikirler, ögretim programı ile ilgili duygular ve ögretim programının uygulanması olmak üzere beş tema içermektedir. Fen lisesi öğretmenlerine uygulanan KÖPDA'da bu beş temada toplam 14 soru bulunmaktadır. $\mathrm{Bu}$ sorulardan ilk altısı kişisel bilgilerin toplandığı sorular olup, mezun olunan üniversite, bölüm, öğretmenlik tecrübesi (y1l cinsinden) ve lisansüstü eğitim durumu gibi bilgileri içermektedir. Yukarıdaki beş tema ile ilgili Şekil 2'de örnekleri verildiği gibi 8 sorunun 22 tane sonda soru ile desteklendiği bir yapı kurgulanmıştır.

1. Yeni kimya öğretim programındaki değişiklikleri aşağıdaki başlıklar
çerçevesinde değerlendiriniz.
a) Öğretmenin rolü açısından
b) Öğrencinin rolü açısından
c) Öğrenme aktiviteleri açısından
d) Değerlendirme açısından
e) Ders kitapları açısından
f) Destek materyalleri açısından
Diğer:
2. Yeni öğretim programı sizin ders işleme stilinizi etkiledi mi?
Cevabınız evet ise;
a) Nasıl değişiklikler olduğunu örnekler vererek açıklayınız.
Cevabınız hayır ise;
Sizce neden etkilememiş olabilir?
3. Yeni öğretim programına sahip misiniz?
Cevabınız evet ise,
a) Yeni öğretim programı açık ve anlaşılabilir mi?
b) Yeni öğretim programı kitabını ders planlarınızda ve ders içi aktivitelerin
hazırlanmasında kullanıyor musunuz?
Cevabınız hayır ise,
a) Niçin yeni öğretim programını edinmediniz?
4. Yeni kimyaöğretim programını ilk incelediğinizdeöğretim programı ile ilgili ne
düşündünüz?
a) Konu yoğunluğu bakımından
b)...


Şekil 2. Veri toplama ve temaların oluşturulmasında kullanılan KÖPDA'da yer alan soruların bir bölümü

\section{Veri Toplama Süreci}

Veriler araştırmacılar tarafından öğretmenler ile bireysel iletişim kurularak onlara posta veya elmek (elektronik mektup) ile gönderilen açık-uçlu sorulardan oluşan anketler ile toplanmıştır. $\mathrm{Bu}$ çalışma kapsamındaki öğretmenlerden daha nitelikli veri almak için onlara çalışmanın amacı, bu çalışmadan elde edilecek verilerin ilgili kurumlarla da akademik yayınlar üzerinden paylaşılacağı, bu çalışma kapsamında eğer ihtiyaç varsa farklı lise türleri ile ilgili farklı öğretim programlarının geliştirilmesinin gerekliliği ile ilgili önerilerin yapılabileceği belirtilmiş bu sebeple anketi olabildiği kadar derinlemesine düşünerek ve samimi bir şekilde doldurmaları rica edilmiştir. Öğretmenlere anketi doldurmaları için belli bir süre tanınmış, anketi dolduran öğretmenlerden anketi araştırmacılara ulaştırması istenmiştir. Bu sırada, eğer varsa, öğretmenlerin anketle ilgili sorularına cevap verilmiş ve ilgili bölümleri daha anlamlı bir şekilde doldurmaları sağlanmıştır. Bu aşamada, bireysel ya da odak grup görüşmesi yapmak yerine anket verilmesinin nedeni öğretmenlere soruları detaylı düşünmeleri için imkân ve zaman sağlamaktır. $\mathrm{Bu}$ sayede, öğretmenlerin görüşme yaparken unutabilecekleri ama belirtmek isteyebilecekleri konular hakkında daha detaylı yazma firsatı verilmiştir.

\section{Veri Analizi}

Toplanan tüm veriler, önce açık kodlama yapılarak kodlanmıştır. Ardından nitel veri analiz yöntemlerinden içerik analizi ile KÖPDA'da yer alan temalar 1şı̆̆ında tümdengelimsel bir yaklaşım ile analiz edilmiştir (Patton, 2002). Verilen cevaplardan, alt temalar altında yeni örüntüler ve kategoriler ortaya çıkmıştır. Kodlama yapılırken içsel türdeşliğe (internal homogeneity) özellikle dikkat edilmiştir. Böylece, kodların birbiri ile uyumu ve aynı tema altında olmalarının tutarlılığı kontrol edilmiştir (Patton, 2002). Oluşturulan kodlar iki yazar arasında sürekli tartışılarak kodlar ve temalar arasındaki tutarlık sağlanmıştır. $\mathrm{Bu}$ süreç sonunda oluşan tema ve kodlar başka iki yazar tarafından da incelenerek öğretmen cevapları ile kodlamaların uygunluğu kontrol edilmiştir. Nihayet, araştırmacılar analizin son aşamasında tartışarak tema ve kodlara son halini 
vermişlerdir (Johnson \& Christensen, 2014). Veri analizlerinden elde edilen kategorilere örnek teşkil etmesi için katılımcı cevaplarından alıntılar yapılmıştır. Bu alıntıların kime ait olduğunu belirtmek için harf ve rakamlardan oluşan üçlü bir kodlama sistemine gidilmiştir. Bu kodlamada ilk ifade katılımcının mesleki deneyimini, ikinci ifade eğitim düzeyini (L: Lisans; Y: Yüksek Lisans; D: Doktora; ve e:eğitime devam ediyor) ve nihayet üçüncü ifade ise hangi bölgede (A: Akdeniz; D: Doğu Anadolu; E: Ege; İ: İç Anadolu; K: Karadeniz; M: Marmara) görev yaptığını belirtmektedir. Örnek olarak, 15 yıllık deneyimi olan, doktora eğitimine devam eden ve Ege bölgesinde görev yapan bir öğretmen “15_De_E” şeklinde kodlanmıştır.

$\mathrm{Bu}$ çalışma, betimsel bir çalışma olmakla birlikte veri toplamada açık-uçlu sorular yer aldığı için olabildiğince detaylı açıklama ve tanımlamalara yer verilmeye çalışılmıştır. Bu nedenle, çalışmanın sonuçları fen lisesi öğretmen görüşlerini kısmen de olsa yansitacak ve benzer durumları araştıran araştırmacılar için kaynak olabilecek niteliktedir.

\section{Bulgular}

Çalışmanın bulguları veri toplama aracı KÖPDA'da yer alan 5 ana tema çerçevesinde şekillenmiş, ancak her bir tema için öğretmenlerin vermiş olduğu cevaplar, KÖPDA'da yer alan 5 ana tema olan ögretim programının yapısı, ögretim programının kabulü, ögretim programının içeriği ile ilgili fikirler, ögretim programı ile ilgili duygular ve ögretim programının uygulanması altında nitel araştırmanın doğasına uygun olarak açık kodlama yapılarak kategorilere ayrılmıştır.

\section{I. Öğretim Programının Yapısı}

Öğretmenlere, 2013'de yürürlüğe giren kimya öğretim programının yapısı hakkındaki görüşleri sorulduğunda verilen cevapların, ögretmenin rolü, ögrencinin rolü, ögrenme etkinlikleri, ders işleme stilleri, ders kitaplarl, destek materyalleri ve ölçmedeğerlendirme olmak üzere 7 kategoride toplandığı görülmüştür.

1. Öğretmenin rolü. 
$\mathrm{Bu}$ kategori için verilen cevaplardan 11'inin (\%41) nicel, 15'inin (\%55) ise nitel değerlendirme içerdiği görülmüştür. Nicel değerlendirmelere bakıldığında (Şekil 3(a)), cevapların 5'i yeni öğretim programının öğretmenin rolünü değiştirmediği yönündeyken, öğretmenin rolünün arttığı ve azaldığı yönünde olan cevaplar eşit sayıda olup 3'er öğretmen tarafından belirtilmiştir. Nitelik açısından yapılan değerlendirmelerde (Şekil 3(b)) ise cevapların 5'i öğretmenin rolünün aktif olduğuna dair bir yaklaşım içermekteyken, 3’ü yapısal olarak öğretmen merkezli bir program olduğu yönündedir. Verilen diğer cevaplarda ise öğretmenin rolünün rehberlik edici, kısmen aktif ve basit olarak nitelendirildiği görülmüştür.

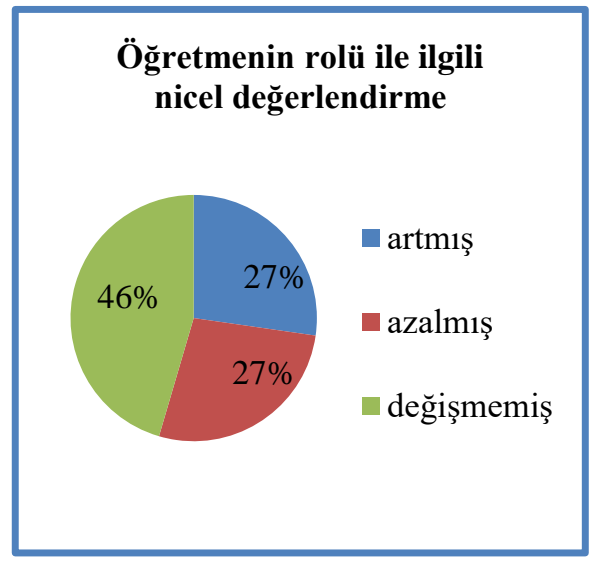

(a)

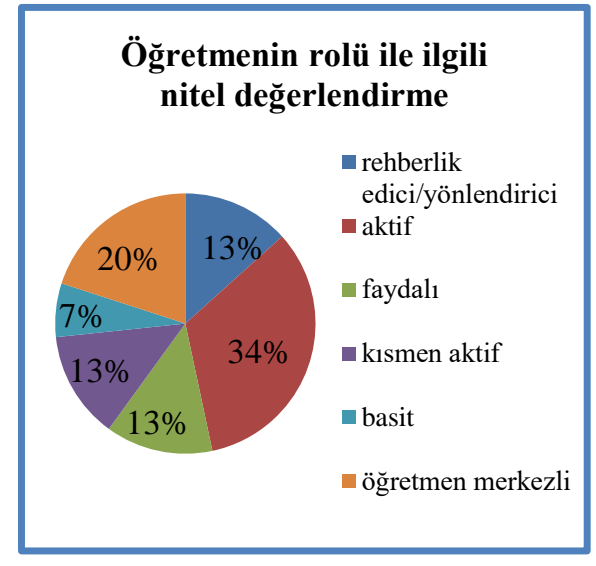

(b)

Şekil 3. Kimya öğretmenlerinin güncellenen kimya öğretim programının yapısını öğretmenin rolü açısından (a) nicel, (b) nitel olarak değerlendirmeleri.

Öğretmenin rolü kategorisinde nitel ve nicel değerlendirmeye yönelik olarak aşağıdaki cevaplar örnek teşkil etmektedir.

“Öğretmen rolü azaltılmış. Özellikle 10. sınıf konuları ögrencilerin sunum hazırlayı, seminer verebilecekleri şekilde hazırlanmış" (nicel, azaltılmış; 21_L_M).

"Öğretmen odakl ögretim programı" (nitel, öğretmen merkezli; 25_L_M). 


\section{2. Öğrencinin rolü.}

Verilen cevaplar incelendiğinde, bu kategoride verilen toplam 18 cevabın 15'inin (\%83) nitel değerlendirme içerdiği görülmüştür. Şekil 4(a)'da görüldüğü üzere, öğrencinin rolünü nitelik açısından değerlendiren öğretmenlerin 7'si öğrencinin aktif, 3'ü pasif ve 2'si faydalı olduğuna görüş belirtirken, diğer cevaplarda öğrencinin rolünün öğretmene bağlı olduğu belirtilmiştir. Öğrencinin rolü kategorisine ilişkin bazı örnek cevaplar aşağıda verilmiştir.

"Öğrencilerin daha etkin olacă̆ bir program hazırlanmış" (nitel, aktif; 21_L_M).

“Öğrenciler alıcı yöndeler, pasifler” (nitel, pasif; 31_L_K).

\section{3. Ögrrenme etkinlikleri.}

Öğretmenlerin bu temaya ilişkin verdikleri 27 cevaptan 20'sinin (\%74) yeni öğretim programın yapısını öğrenme etkinlikleri yönünden de ele aldıkları görülmüştür. Bu cevaplardan 8'i etkinlikler hakkında olumlu (başarılı, faydalı vb.), 9'u olumsuz (yetersiz, eksik vb.) değerlendirmelerde bulunurken, 2'sinin yeni öğretim programının etkinlik ağırlıklı olduğuna dair görüş bildirdiği görülmüştür (Şekil 4(b)). Geri kalan 7 cevabın ise öğrenme etkinlikleri ile ilgili öneri niteliği taşımakta olduğu belirlenmiştir.

Öğretim programının öğrenme etkinlikleri açısından da ele alındığını gösteren öğretmen görüşlerine örnekler aşağıda verilmiştir.

“Öğrenme aktiviteleri bakımından, etkinliklere sıkça yer verilmiş, ancak birçoğu çok basit olduğundan ögrencilerin ilgisini çekmiyor" (nitel, etkinlik ağırlıklı; 21_L_M).

"Öğrenme aktiviteleri açısından eski programla herhangi bir farkın ortaya çıktı̆̆ını gözlemlememekteyim”(nitel, eski programla ayn1; 15_Y_E). 


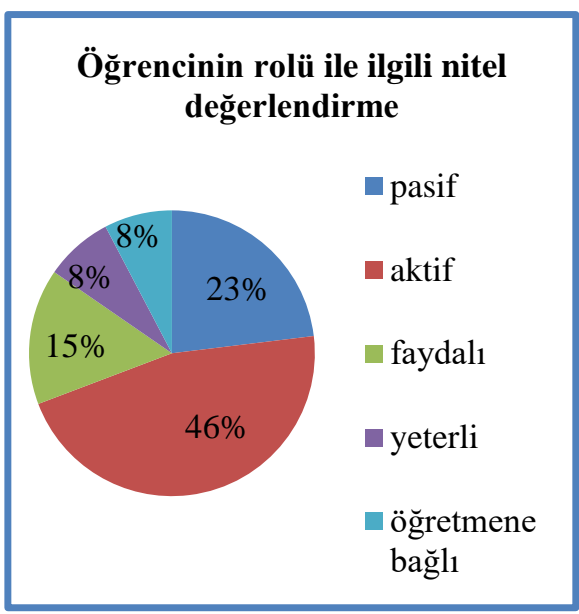

(a)

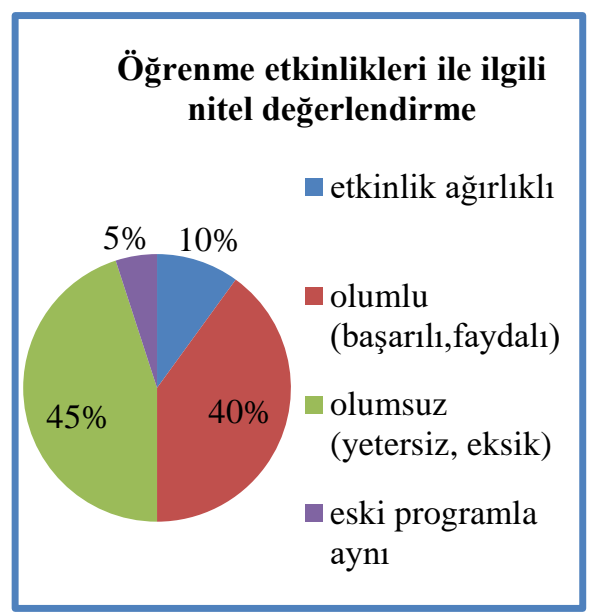

(b)

Şekil 4. Kimya öğretmenlerinin, güncellenen kimya öğretim programının yapısını (a) öğrencinin rolü, (b) öğrenme etkinlikleri açısından nitel olarak değerlendirmeleri.

\section{Ders ișleme stilleri.}

$\mathrm{Bu}$ temada ortaya çıkan diğer bir kategori olan "Ders işleme stilleri" kategorisine 42 öğretmenin 31'inin (\%78) değindiği gözlenmiştir. $\mathrm{Bu}$ bağlamda, 'etkilediği' yönünde verilen 6 cevaptan 3'ü programın yapısından dolayı öğrencilerle daha fazla sözel etkileşim içerisinde olduklarına dair görüş belirtirken, diğer öğretmenlerin eşit oranlarda öğretmenin tahtada daha fazla zaman geçirdiğini, çoklu öğretim yöntemlerini kullandığını ve ders kitabına daha bağımlı hale geldikleri görüşünde oldukları gözlenmiştir (Şekil 5(a)). Öğretmenlerin öğretim programının yapısının ders işleme stillerini nasıl etkilediğini gösteren görüşlerinden birkaçı aşağıda görülmektedir.

"Günlük hayattan daha çok konu var. Kimya programının sözele ve ezbere kaydı̆̆ını görüyorum” (sözel etkileşim; 15_De_E).

"Görsel materyalleri daha fazla kullanıyorum” (çoklu yöntem kullanımı; 21_L_K). 
"Ders aktarımı yerine daha çok ısındırıcı sorular sorarak başlıyorum. Uygun zaman bulabilirsem grup çalışmaları yaptırıyorum”" (çoklu yöntem kullanımı; 21_D_M).

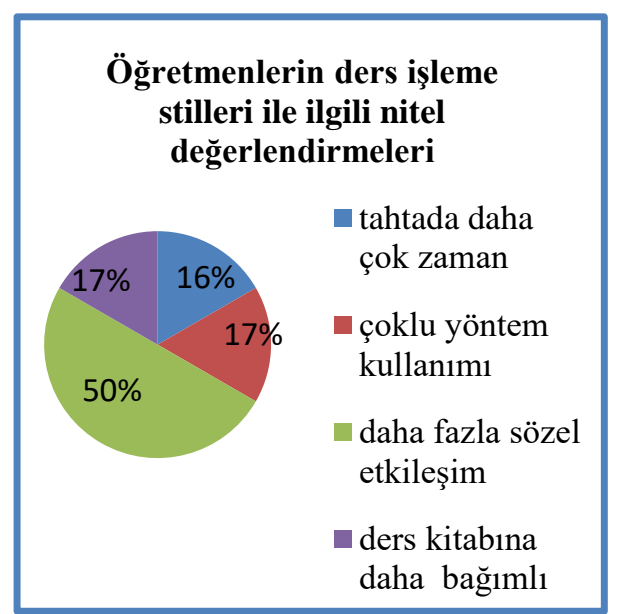

(a)

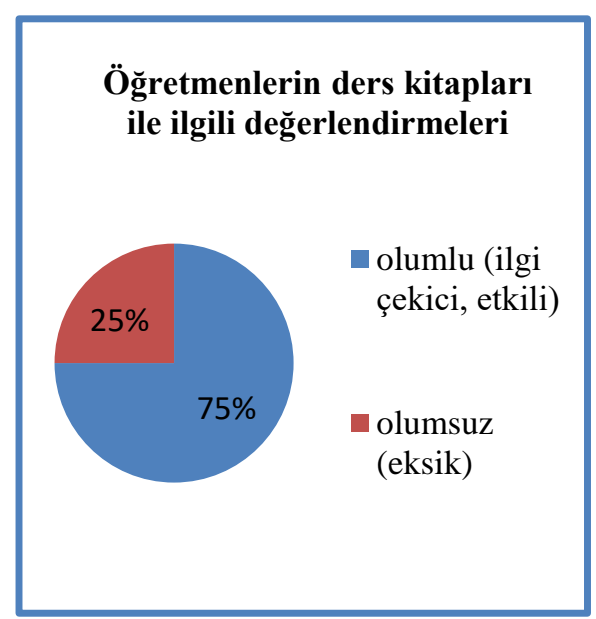

(b)

Şekil 5. Kimya öğretmenlerinin, güncellenen kimya öğretim programının yapısını (a) öğretmenlerin ders işleme stilleri, (b) ders kitapları açısından nitel olarak değerlendirmeleri.

\section{Ders kitapları.}

Öğretmenlerin programın yapısı ile ilgili değerlendirmelerinde öne çıkan başka bir boyutun ise öğretmenlerin verdiği 39 cevabın 36'sının (\%93) değindiği ders kitapları olduğu görülmüştür. Bu bağlamda, Şekil 5(b)'de görüldüğü üzere, öğretmenlerin 27'si ders kitaplarının içeriği ile ilgili olumlu görüş bildirirken, 9'u program ile karşılaştırıldığında eksikliklerin olduğunu söylemişlerdir. Ders kitapları ile ilgili değerlendirme yapan öğretmenlerin verdikleri cevaplara iki örnek aşağıda verilmiştir.

"Genelde 9. sinıf konuları önceki yıllarda olduğu gibi ama özellikle etkinlik ve bilgi açısından şu anki daha etkili ve tatmin edici" (olumlu; 31_L_K). 
S.Akaygün, R.Elmas.../ EÜ Eğitim Fakültesi Dergisi, 18-2 (2016),737-770

"Ders kitabı öğretim programı çerçevesinde tekrar hazırlanmal, verilmesi gereken bazı noktalar atlanmış" (olumsuz; 15_De_E).

\section{Destek materyalleri.}

Öğretmenlerin öğretim programının yapısını değerlendirirken destek materyalleri de göz önünde bulundurdukları verilen 34 cevabın 32'sinde (\%94) görülmüştür. $\mathrm{Bu}$ kategoriyi program değerlendirmelerine dahil eden öğretmenlerin 20'si destek materyallerinin kullanımı ile ilgili olumlu görüş bildirirken, 12'si ise yetersizlikler nedeniyle destek materyaller konusunda olumsuz görüşleri olduğunu söylemişlerdir (Şekil 6(a)). Bu kategoride öğretmenlerin hem teknolojik araç-gereçleri hem de laboratuvar malzemelerini destek materyali olarak gördükleri gözlenmiştir. Destek materyalleri kategorisinde ele alınmış öğretmen cevaplarına iki örnek alıntı aşağıda verilmiştir.

"Sinıflarda akıllı tahtaların olmasinin avantajlart oluyor. Örneğin konu ile ilgili görselleri sunma, animasyonlar izleme imkanı veriyor" (olumlu; 21_L_M).

"Laboratuvar araç gereçleri programa uygun tedarik edilmeli” (olumsuz; 15_De_E). 


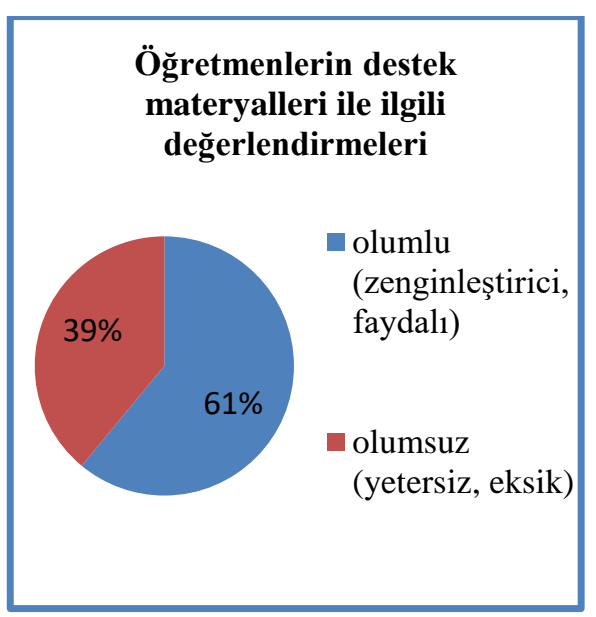

(a)

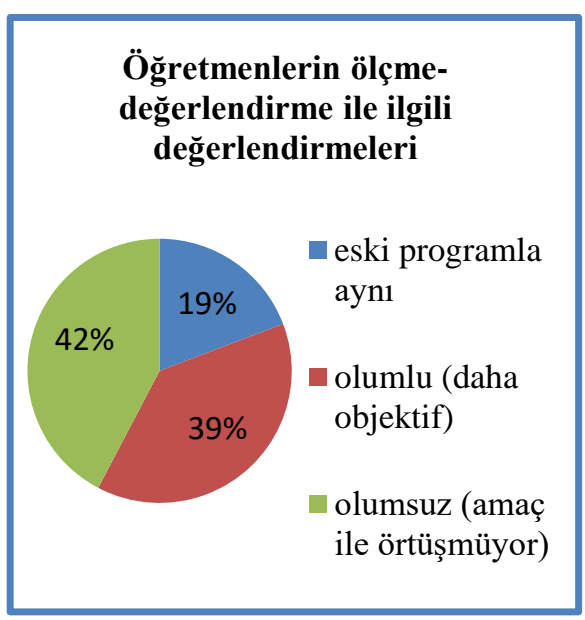

(b)

Şekil 6. Kimya öğretmenlerinin, güncellenen kimya öğretim programının yapısını (a) öğretmenlerin destek materyaller, (b) ölçme-değerlendirme açısından nitel olarak değerlendirmeleri.

\section{7. Ölçme-değerlendirme.}

Programın yapısı temasında öne çıkan kategorilerden biri olan 'Ölçme-değerlendirme' kategorisine öğretmenlerin verdikleri toplam 32 cevabın 26'sında (\%81) vurgu yaptıkları görülmüştür. $\mathrm{Bu}$ bağlamda öğretmen görüşlerinin 10'u olumlu, 11'i olumsuz, 5'i ise değerlendirme açısından güncellenen programın bir önceki programdan farkının olmadığı yönünde olmuştur (Şekil 6(b)). Öğretmenlerin programın yapısını ölçme-değerlendirme açısından değerlendirdiklerini gösteren cevaplarına birkaç örnek aşağıda verilmiştir.

"Değerlendirme yeni müfredat programında eskiye göre daha iyi. Ancak programda örnek değerlendirme etkinlikleri verilmelidir (olumlu; 20_L_K).

"2013 öğretim programında [bir önceki programa göre] değerlendirme metotlarl yönünden anlamlı bir fark olmamıştır" (eski programla aynı; 13_Y_E). 


\section{II. Öğretim programının kabulü}

KÖPDA'da yer alan ikinci tema olan ögretim programının kabulü ile ilgili olarak çalışmaya katılan öğretmenlere yeni kimya programına sahip olup olmadıkları, programı açık ve anlaşılabilir bulup bulmadıkları ve yeni öğretim programı kitapçığını ders planlarının ve ders içi aktivitelerin hazırlanmasında kullanıp kullanmadıkları sorulmuştur. Araştırmaya katılan öğretmenlerin hepsi yeni kimya öğretim programına sahip olduklarını belirtirken, 30'u programı açık ve anlaşılabilir bulduklarını ifade etmişlerdir (Şekil 7(a)). Öğretim programının hangi amaçla kullanıldığı sorusuna ise cevap veren öğretmenlerin 30'u yeni öğretim programı derse hazırlık sürecinde kullandıklarını, 7'si ise bazen kullandıklarını ifade etmiştir (Şekil 7(b)).

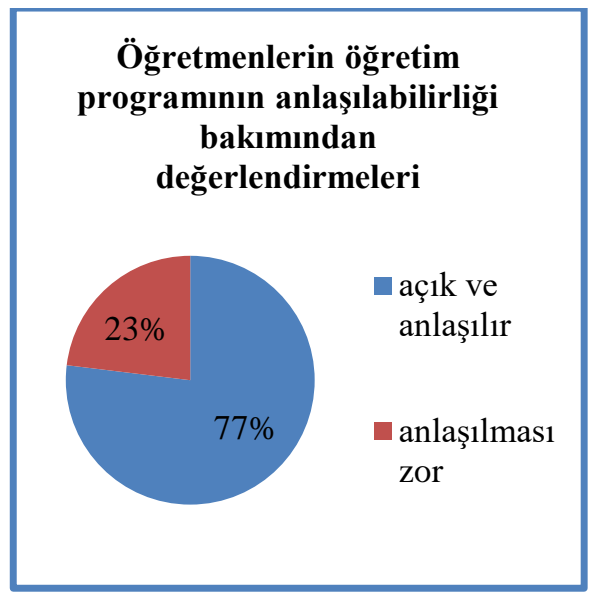

(a)

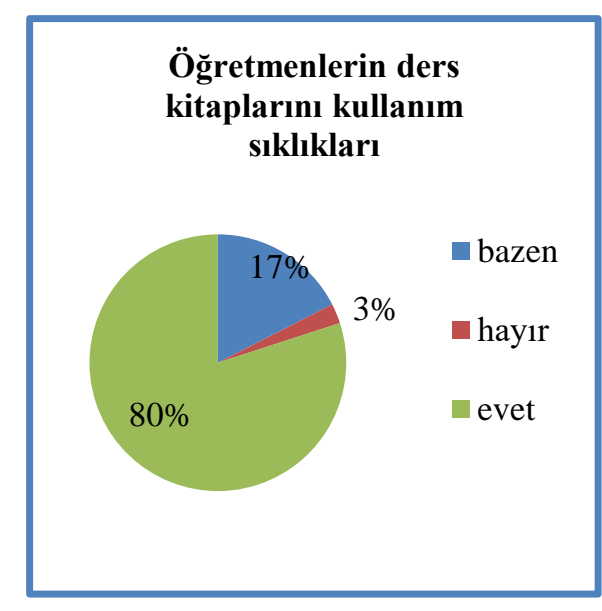

(b)

Şekil 7. Kimya öğretmenlerinin, (a) güncellenen kimya öğretim programını anlaşılabilirliği bakımından değerlendirmeleri, (b) ders kitaplarını kullanım s1klıkları.

\section{III. Öğretim programının içeriği ile ilgili görüşler}

$\mathrm{Bu}$ tema altında, öğretmenlerden öğretim programının içeriğini, konuların yoğunluğu ve organizasyonu, konuların birbiriyle 
ve günlük hayatla ilişkilendirilmesi ve konuların zorluk düzeyi açısından değerlendirmeleri istenmiştir.

\section{1. Öğretim programındaki konuların yoğunluğu ve organizasyonu.}

$\mathrm{Bu}$ kategoride verilen toplam 65 cevaptan, 16's1 genel bir değerlendirme içerirken, sırasıyla 18,12, 13 ve 6 cevap 9., 10., 11. ve 12. sinıf ögretim programında yer alan konuların çok yoğun olduğuna dair görüş belirtmiştir (Şekil 8). Konuların yoğunluğu ile ilgili öğretmen görüşlerinden bir kaçına aşağıda yer verilmiştir.

"9. sinuf çok yoğun, 10. sinıf ezber bilgi veriyor ve yoğunluğu düşük” (yoğun, az yoğun; 19_L_E).

"9. sınıf çok yoğun 10. sınıf çok boşaltılmış biyoloji konularına fazla yer verilmiş 11. sinıf inanılmaz çok yoğun buluyorum” (yoğun, çok yoğun; 31_Ye_M).

Öğretmenlere konuların organizasyonu ile ilgili görüşleri sorulduğunda ise öğretmenlerin verdiği toplam 28 cevaptan 15 'inin (\%54) düzensiz, yetersiz gibi nedenler ile olumsuz görüş bildirdikleri gözlenirken, 11'inin programdaki konuların organizasyonunu başarılı ve yeterli bulduklarını söyleyerek olumlu görüş bildirdikleri gözlemlenmiştir. Geriye kalan öğretmenler ise konu organizasyonu bakımından güncellenen programının bir önceki programdan farkının olmadığını belirtmişılerdir. Konuların organizasyonu ile ilgili birkaç öğretmen görüşü aşağıda yer almaktadır.

"Organizasyon sırasinda yanlışlıklar var. Atom modelleri tamamlandıktan sonra atomun iç yapısı verilmelidir" (olumsuz, öneri; 11_Y_K).

"Konular arasında bütünleyiciliğin sağlanması yeterli düzeydedir" (olumlu; 12_Y_D). 


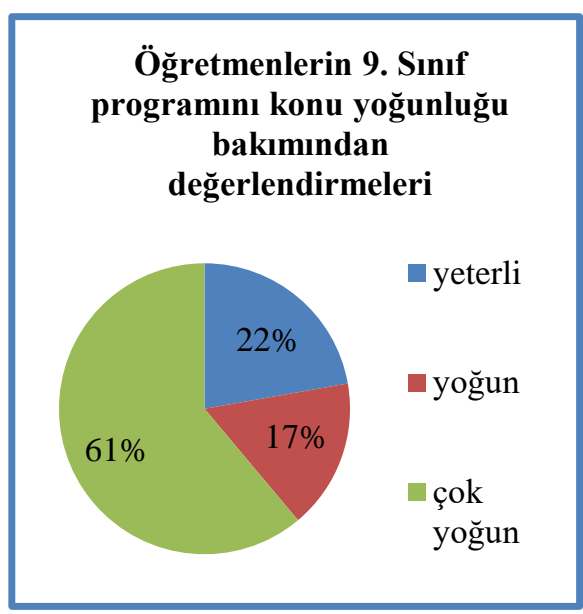

(a)

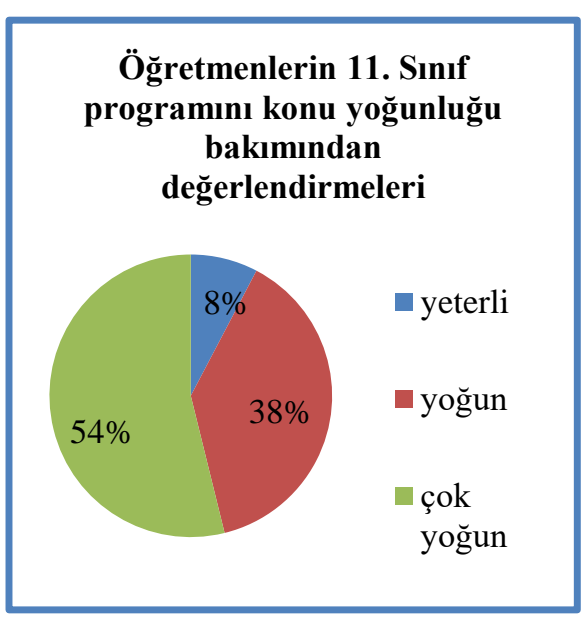

(c)

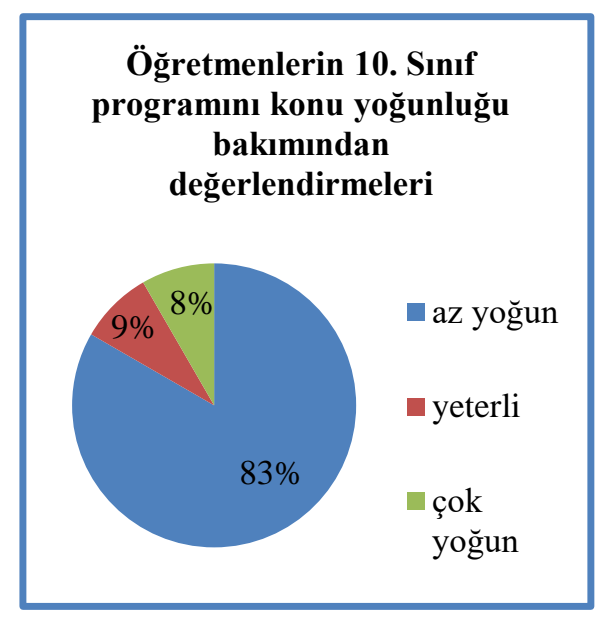

(b)

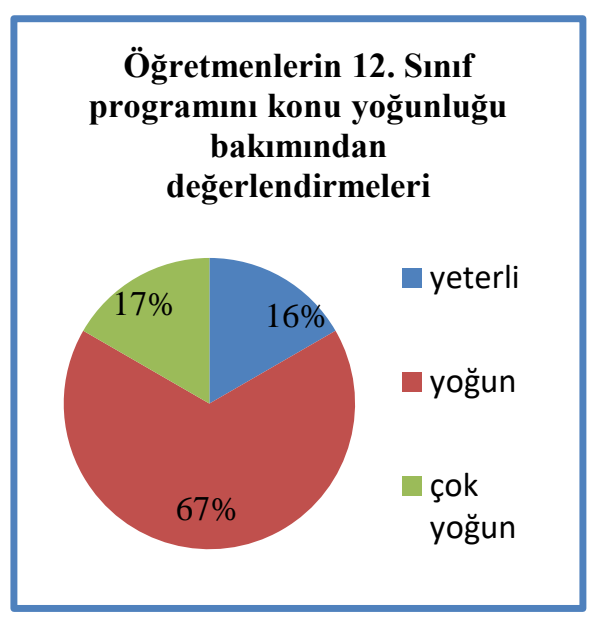

(d)

Şekil 8. Kimya öğretmenlerinin, güncellenen kimya öğretim programını konu yoğunluğu bakımından (a) 9. Sınıf, (b) 10. Sınıf, (c) 11. Sınıf, (d) 12. Sinıf için değerlendirmeleri.

\section{2. Öğretim programındaki konuların birbiriyle ve günlük hayatla ilişkilendirilmesi.}


Konuların birbiriyle ilişkisi için verilen toplam 30 cevaptan 18'inin (\%60) olumlu değerlendirme niteliğindeyken, 10'unun olumsuz görüş içerdiği, 2'sinin ise öneri niteliğinde olduğu görülmüştür. $\mathrm{Bu}$ cevaplara iki örnek aşağıda verilmiştir.

“Konular birbirleriyle iliş̧kili” (olumlu; 19_L_E).

"Bazı konular verilirken bağlantı kurulmamış. Örneğin, 9. sinuflarda atom ve yapisindan önce kismen de olsa adlandirmaya girilmesi" (olumsuz; 15_L_M).

Konuların günlük hayat ile ilişkili olup olmaması ile ilgili görüsslerde ise ögretmenlerin verdiği toplam 40 cevaptan 30'u (\%75) olumlu iken 9'unun olumsuz olduğu belirlenmiştir. Bu kategorideki olumlu cevaplara örnek olarak aşağıdaki alıntı verilmiştir.

“Öğretilen konuların günlük hayatla ilişkilendirilmeleri bakımından güzel” (olumlu; 21_L_M)

\section{3. Öğretim programındaki konuların zorluk düzeyi.}

Çalışmaya katılan öğretmenlerin verdiği toplam 21 cevaptan 12'si programın fen lisesi öğrencileri için zor olmadığını belirtmiştir.

"Fen lisesi ögrencileri açısından basit fakat diğer lisedeki ögrenciler ileri kimya (11 ve 12 . sinuf) konularında zorlanabilir" (zor değil; 29_L_A).

\section{IV. Öğretim programı ile ilgili duygular}

$\mathrm{Bu}$ tema kapsamında öğretmenlere öğretim programı ile ilgili duyguları sorulmuş ve öğretmenlerin verdiği 32 cevaptan 20'sinde olumlu (yeterli, mutlu vb.), 12'sinde ise olumsuz duygu (yorgun, mutsuz vb.) içeren ifadelerin yer aldığı gözlenmiştir. Öğretmenlere bu duygularının nedenleri sorulduğunda ise, Şekil 9'da görüldüğü gibi, bazı öğretmenlerin farklı gerekçeler ileri sürdükleri görülmüştür. Gerekçe sunan öğretmenler, olumlu duygularının nedenlerini öğrenciler (3), alan bilgisi (2), öğretim programı (2), mesleki tecrübe (1) ve mesleki doyum (1) olarak sıralamışlardır. Olumsuz duyguların 
nedenleri olarak ise öğretim programının içeriği (3), programın yapısı (2) ve zamanlamayı (1) belirtmişlerdir. Bu duyguların genellikle öğrencilerinin ya da kendilerinin kazanımları ile ilgili olduğu görülmektedir. Aşağıda olumlu ve olumsuz duygulara yönelik olarak birer örnek cevap verilmiştir.

"Tatlı bir yorgunluk hissediyorum. Çünkü ögrrenciler derse aktif bir şekilde katılıyorlar" (olumlu, öğrenciler; 12_Y_D).

"9.sınıfi 2 saatte yetiştirmek zor" (olumsuz, zamanlama; 21_D_M).

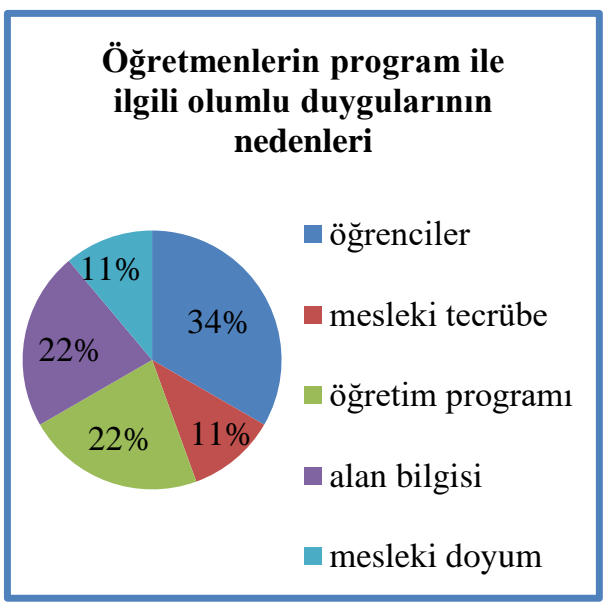

(a)

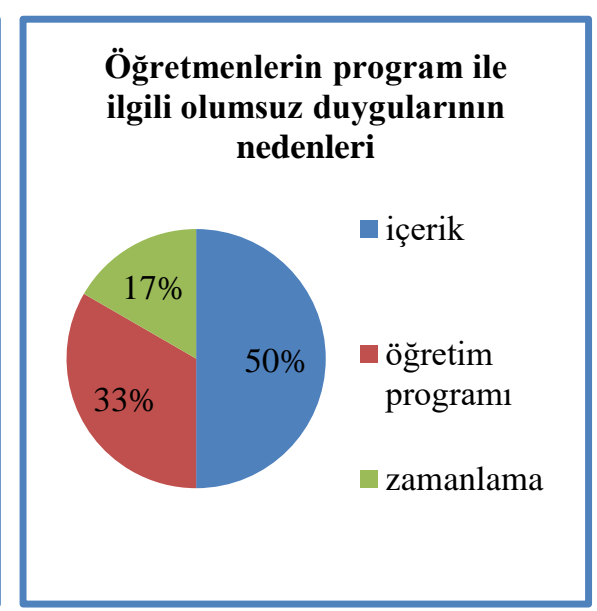

(b)

Şekil 9. Kimya öğretmenlerinin, güncellenen kimya öğretim programı ile ilgili (a) olumlu, (b) olumsuz duygularının nedenlerinin dağılımı.

\section{V. Ö̆̆retim programının uygulanmasına etki eden faktörler}

$\mathrm{Bu}$ ana tema altında, çalışmaya katılan öğretmenlere yeni öğretim programının uygulanmasına etki eden unsurlar ve programa eklenmesini ya da çıkarılmasını istedikleri konular sorulmuştur. Öğretmenlerin verdikleri toplam 37 cevaptan $11^{\prime} \mathrm{i}$ (\%30) programın uygulanmasına etki eden unsur olarak fiziksel şartları içerirken, 10'u öğrencileri ve 5'i ise planlamaya dair çeşitli unsurları (ders saatinin 
azlığı vb.) ele almıştır (Şekil 10). Öğretmenlerin bu temaya yönelik olarak verdiği cevaplara örnekler aşağıda verilmişstir.

"Ders saatinin azlığl nedeniyle laboratuvara yeterli zaman ayıramıyoruz. Bu sadece bu programa özgü değil. Diğerlerinde de ayn idi" (Zamanlama; 21_L_M).

"Fen lisesi ögrrencileri çoğunlukla bilinçli ailelerin çocukları oldukları için yenilikleri takip ediyorlar ve ögretmenleri bu konuda yönlendirebiliyorlar" (Öğrenciler; 28_L_İ).

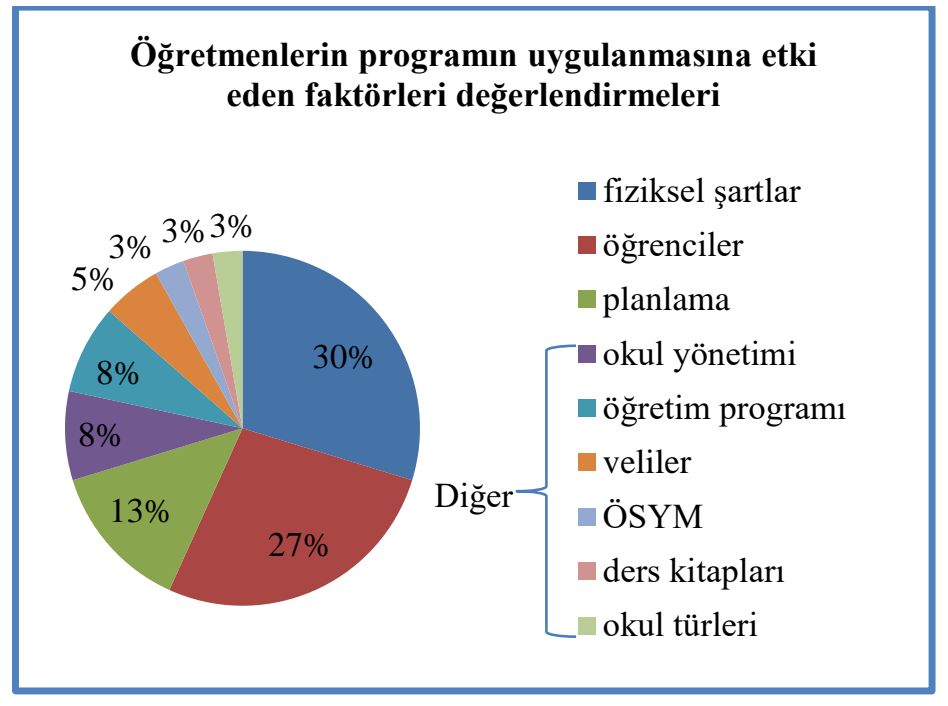

Şekil 10. Kimya öğretmenlerinin, güncellenen kimya öğretim programının uygulanmasına etki eden faktörleri değerlendirmeleri.

Ayrıca, öğretmenlerin verdikleri toplam 44 cevaptan 38 'i (\%86) programdan çıkarılması istenen konulara dair görüş içermekteyken, 6'sı programa eklenmesi yada daha fazla yer verilmesi gereken konulara dair görüş içermekte olduğu görülmüştür. Özel olarak, öğretmenler manometre ve radyoaktiflik konularının yeniden programa eklenmesini isterken; 9. sınıf için kimyanın tarihçesi, spektrum çeşitleri, atom teorilerinin, 10. sınıflarda günlük yaşantıda kimya, asit ve tuzların kullanım alanları, canlılarda enerji konularının, 
11. sinıfta Entropi ve 12. sinıfta ise Hayatımızda Kimya ünitesinin çıkarılmasının uygun olacağı görüşündedirler.

\section{VI. Öneriler}

Zaman zaman öğretmenlerin kendilerine yöneltilen sorulardaki temalar doğrultusunda ya da temanın dışına çıkarak önerilerde bulundukları gözlemlenmiştir. Öğretmenlerin önerilerinin genellikle içerik, planlama, ölçme-değerlendirme, konuların organizasyonu, destek materyal kullanımı ve ders kitapları yönünde olduğu gözlenmiştir. Öğretmenler tarafından yapılmış önerilere birkaç örnek aşağıda verilmiştir.

"Ders saatinin azliğı nedeniyle laboratuvara yeterli zaman ayıramiyoruz, laboratuvara zaman aytrabilmek isteriz" (planlama; 21_L_M).

“Özellikle 11. ve 12. sinfflarda uygulanacak olan ileri düzey kimya dersi için haftalı 4 saatin yeterli olmayacağını düşünüyorum. Bana göre fen liselerinde 9. ve 10. sinuflarda kimya dersini haftada 3 saat yaparsak 11. siniftaki konulardan 1 veya 2 tanesini bu siniflara kaydirabiliriz" (planlama, konuların organizasyonu; 13_Y_ì).

“Öğretim programına zorunlu olarak bağlı olmak zorundayız çünkü üniversite sınavlarında aynı programdan sorumlu oluyorlar. Oysa fen liseleri için ögrretim programı farklılaştırılabilir" (içerik; 17_L_M).

\section{Tartışma ve Sonuç}

Bir öğretim programının en etkili ve objektif değerlendirmesinin ancak programın uygulayıcıları olan öğretmenlerin görüşleri alınarak yapılabileceği düşünülmektedir (Ekiz, 2004). Bu nedenle, 2013'te güncellenerek uygulanmaya başlanan kimya dersi öğretim programı Türkiye'nin 7 farklı 
bölgesinde görev yapmakta olan 42 fen lisesi kimya öğretmeni tarafindan ögretim programının yapısı, ögretim programının kabulünü, öğretim programının içeriği ile ilgili fikirler, ögretim program ile ilgili duygular ve ögretim programın uygulanmasına etki eden faktörler kapsamında değerlendirilmiştir. 2013 yılında güncellenen kimya öğretim programının öğretmen görüşleri doğrultusunda incelenmesine yönelik başka bir çalışmaya rastlanmamış olup bu nedenle çalışmanın alanyazına katkı sağlayacağı düşünülmektedir. Çalışmada, programının dayandığı felsefi temellerin bir önceki programa göre çok büyük farklılık göstermediği fikri genel olarak ifade edilmiştir. Öğretmenler, sisteme, programın içeriği ve yapısı ile ders kitap ve materyallerine yönelik öneriler getirirken, ögretim programlarının okul türlerine uygun olarak farklılaştırılmasına vurgu yapmışlardır (Seçken \& Kunduz, 2013).

Öğretmenler tarafından yapılan değerlendirmelerde, yürürlükte olan öğretim programının yapısına ilişkin olarak, çoğunlukla öğretmenin rolünün bir önceki programa göre fazla değişmediği, öğrencinin aktif olan rolünün ise daha da arttığı, öğrenme etkinlikleri açısından fazla bir değişiklik olmadığı, öte yandan yeni programın daha fazla sözel konular içermesi nedeniyle sözel etkileşimin arttığı, bu bağlamda yeni programa göre hazırlanmış olan ders kitaplarının tatmin edici olduğu, mevcut destek materyallerin program ile örtüştüğü, ölçme-değerlendirme açısından ise olumlu veya olumsuz açık bir eğilimin oluşmadığı gözlenmiştir.

Ayrıca, öğretmenlerin hepsinde program kitapçı̆̆ının bulunması, büyük çoğunluğunun programı açık ve anlaşılır bulması ve ders kitaplarını büyük oranda kullanmaları programı kabul etmiş olmalarının göstergesi olarak kabul edilebilir. Elde edilen bu sonuç, Demircioğlu vd.'nin (2015) öğretmenlerin öğretim programını yeterince incelemedikleri bulgusu ile çelişmektedir. $\mathrm{Bu}$ çelişkinin sebebi mevcut çalışmada fen lisesi öğretmenlerine odaklanılması olabilir. Başka bir ifadeyle fen lisesi öğretmenlerinin diğer okul türlerinde görev yapan öğretmenlere göre öğretim programını daha yakından takip ettikleri söylenebilir.

Programın içerik olarak değerlendirilmesinde, öğretmenlerin çoğunluğu programda yer alan konuların öğrenciler için hiç zor 
olmadığını belirtmiştir ki, bu durum özellikle fen lisesi öğrencilerinin profili düşünüldüğünde şaşırtıcı olmayan bir bulgudur. Sınıf bazında yapılan içerik değerlendirmelerinde ise, öğretmenler temel düzey olan 9. sınıf konu ve kazanımlarının, yoğun olmakla birlikte fen lisesi düzeyine uygun; ancak 10. sinıfin özellikle Endüstride ve Canlılarda Enerji ile Hayatımızda Kimya ünitelerinde yer alanlar başta olmak üzere çoğu konu ve kazanımlarının sözel ağırlıklı ve ezbere yönlendirici olduğunu belirtmişlerdir. 11. ve 12. sınıf konularının ise çok yoğun ve zamanın sınırlı olduğu belirtilmiştir. Buna bağlı olarak, öğretmenlerin çoğunluğu 9., 11. ve 12. sinıflarda mevcut ders saatleri dahilinde laboratuvar çalışması yapmaya vakitlerinin olmadığını vurgulamışlardır. Benzer bulgular Demircioğlu vd. (2015) ile Seçken ve Kunduz (2013) tarafından da rapor edilmiştir. Ancak, kuramsal bilginin yanı sıra uygulamanın ve yaşamsal becerilerin geliştirilmesi beklenen fen lisesi öğrencileri açısından bu durum oldukça düşündürücüdür.

Ek olarak, öğretmenlerin çoğunluğu programda yer alan konuların günlük hayat ile ilişkili olduğu yönünde olumlu görüş bildirmiştir. Bu bulgu, Mercan'ın (2014), 2007 yılında geliştirilen Ortaöğretim Kimya Dersi Öğretim Programı'nın içeriği ve kurgusu hakkındaki öğretmen görüşlerini incelediği çalışmasının bulguları ile de uyumludur. Ancak Mercan'ın (2014) diğer bulguları olan sarmal konu sıralanışının gereksiz bulunması ile fizik ve biyoloji konularının kimya içeriğine katılmasına olumsuz bakılmasına bu çalışmadan elde edilen bulgularda fazla rastlanmamıştır. Bunun nedeni çalışmanın fen lisesi öğretmenleri ile yürütülmüş olması olup, bu özelliklerin fen lisesi öğrencilerinin ihtiyaçlarına uygun olduğu söylenebilir.

Uygulama sürecinde, ögretim programına yönelik duyguların çoğunlukla olumlu olması ve bunun nedeninin de ya öğrencilerin ya da öğretmenlerin kazanımlarından kaynaklanıyor olması dikkat çekicidir. Olumsuz duyguların ise yine programın istenilen şekilde işlenemeyecek olmasından ve fen lisesi öğrencilerinin süre darlığı, konu yoğunluğu gibi nedenler yüzünden kazanımları istenilen şekilde tamamlayamayacak olmalarından kaynaklandığı söylenebilir. $\mathrm{Bu}$ çalışma, sadece fen liselerinde yürütülmüş olsa da bu bulgunun tüm lise türlerine genellenebileceği düşünülebilir. Çünkü bu duygulara 
neden olan durumların önceki çalışmalarda da öne sürüldüğü görülmektedir (Demircioğlu vd., 2015; Mercan, 2014; Seçken \& Kunduz, 2013). Özetle bu çalışmada, duygular öne çıkarılırken, duyguların nedenleri de sorgulatılmıştır.

Programın uygulanmasına etki eden faktörler bağlamında ise ortaya çıkan faktörlerin başında gelen 'fiziksel şartlar' önceki çalışmalar (Çalık, 2016; Demircioğlu vd., 2015) ile paralellik göstermektedir. Çünkü zaman kısıtlaması nedeniyle yapılamayan laboratuvar uygulamaları aslında programın öngörülen nitelikte uygulanmasına ket vurmaktadır. İkinci önemli unsur olarak öne çıkan 'öğrenciler' ise yeni bir bulgudur. Bu durum, fen lisesi öğrencilerinin bu konuda daha bilinçli olduklarının göstergesi olarak yorumlanabilir.Diğer liselerden farklı olarak fen lisesi öğrencileri öğretim programının işlenişini takip ediyor ve öğretmenlerini bu konuda yönlendiriyor olma olasılığı önem arz etmektedir. Bu bulgu, fen lisesi öğrencilerinin profillerinin farklı olduğunu bir kez daha ortaya koymakta ve farklılaştırılmış bir programın gerekliliği çıkarımına vurgu yapmaktadır.

Programa yönelik getirilen önerilerde, öğretmenlerin planlamaya dikkat çektiği; ders saatinin azlığı nedeniyle laboratuvar çalışmalarına daha fazla zaman ayırmak istemelerine rağmen yeterince ayıramadıklarını söyledikleri tespit edilmiştir. $\mathrm{Bu}$ öneri, Çalık'ın (2016) kimya dersi öğretim programının öğrencilerin bilimsel süreç becerilerini geliştirmeye yönelik olduğu ve öğretmenlerin daha fazla laboratuvar uygulaması yapmalarının önemini savunması ile örtüşmektedir. Fen lisesi öğretmenleri ayrıca, öğrencilerin aynı sınav sistemine tabi olduklarını da belirtmişlerdir. Bu bulgu da Çalık'ın (2016), mevcut sınav sisteminin öğretmenleri araştırmaya-dayalı fen eğitimi yürütmek yerine geleneksel öğretim yöntemlerine yöneltmekte olduğu görüşü ile uyumludur. Çünkü yeterli ders saati olmadığı için laboratuvar çalışması yapamamaktan yakınan öğretmenler, üniversite sinavına girmek durumunda olan öğrencilerini sinava hazırlamak adına geleneksel yöntemleri tercih etmektedirler. Oysa bu durum, fen liselerinin kuruluş amacı ve öğrencilerin ihtiyaçları ile örtüşmemekte; dolayısıyla öğretim programının ve bununla ilişkili olarak üniversiteye giriş/geçiş sisteminin fen liseleri için farklılaştırılmasını gündeme 
getirmektedir. Özetle, çalışmada elde edilen bulguların daha önceki araştırmalarda (Çalık, 2016; Demircioğlu vd., 2015) ortaya çıkmış olan "zaman darlığı", "fiziksel şartların uygun olmaması", "sınav sistemi nedeniyle öğretimin laboratuvarsız olması" gibi konuları içeriyor olması fen lisesinde görev yapan öğretmenlerin de benzer durum ve sorunlar ile karşı karşıya kaldıklarının bir göstergesi olduğu düşünülmektedir.

Sonuç olarak, fen liselerinde okutulan kimya dersi öğretim programı ile diğer liselerde okutulmakta olan program aynıdır; oysa fen lisesi öğrencilerinin okul türleri nedeniyle daha farklı ihtiyaçlarının olduğu düşünülmelidir. $\mathrm{Bu}$ nedenle, öğretmenlerin bu konudaki deneyim ve izlenimlerinin dikkate alınarak kimya ögretim programının yeniden yapılandırılması önem kazanmaktadır. $\mathrm{Bu}$ çalışmanın gerek bundan sonra yapılacak araştırmalara gerekse program düzenleme çalışmalarına 1şık tutacağı umut edilmektedir.

Her bilimsel çalışma belirli varsayımlar ve sınırlılıklar dahilinde gerçekleştirilir. Mevcut çalışmadan elde edilen sonuçların daha iyi değerlendirilmesi için bu sınırlılıklara değinmek gerekir. Çalışmada dikkati çeken en önemli sınırlık genele ve daha çok öğretmene ulaşma amacı doğrultusunda seçilen veri toplama yönteminden elde edilen bulguların derinliğidir. Veri toplama aracı olarak kullanılan KÖPDA açık uçlu sorulardan oluşmaktadır. Bu bağlamda katılımcıların öğretim programına yönelik deneyim ve görüşlerini, önceden belirlenmiş kalıpların dışına çıkarak, daha iyi açıklamasına imkan tanınmıştır. Öğretmenler sorular ile ilgili deneyimlerini daha sağlıklı düşünerek cevaplayabilmişlerdir. Ancak, öğretmenlerin verdikleri cevaplar her ne kadar iyi düşünülmüş ve öz bir şekilde ankete aktarılmış olsa da bu görüşlerin gerekçeleri çoğu zaman ankette yer almamıştır. $\mathrm{Bu}$ durum tutarlı bir şekilde öğretmenlerin ifadelerinin ardında yatan yapıyı belirlemeye imkan tanımamaktadır. $\mathrm{Bu}$ nedenle elde edilen bulgular öğretmenlerin deneyimlerinden süzülerek elde edilmiş olmakla birlikte bazı durumlarda yeterince açıklayıcı olamamaktadır. Ancak, bu durum elde edilen verilerin öğretmenlerin programa yönelik görüşlerinin çeşitliliği ve daha genel bir çerçevede değerlendirilmesine engel olmamaktadır. 


\section{Öneriler}

Öğretim programları hazırlanırken pek çok unsur göz önünde bulundurulmaktadır. $\mathrm{Bu}$ unsurlardan bazıları benimsenen öğretim yaklaşımı, güncel bilimsel konular ve teknolojik gelişmeler ve bilimsel okur-yazarlık kriterleri olarak siralanabilir. Öte yandan, bulundukları okul türlerine göre öğrencilerin ihtiyaçları farklılaşmakta; öğretmenlerin deneyimleri ise bu ihtiyaçların ön plana çıkarılmasında yol gösterici olmaktadır. Özetle, fen liselerinde okumakta olan öğrencilerin ihtiyaçları diğer liselerde okumakta olanlara göre daha farklıdır. Çünkü bu öğrencilerin tümü fen derslerine ilgi duymalarından ve ileride fen ile ilgili bir meslek sahibi olmak istemelerinden dolayı fen liselerini tercih etmişlerdir. $\mathrm{Bu}$ nedenle, fen dersleri öğretim progamlarının da bu doğrultuda yeniden yapılandırılması önerilebilir.

Öte yandan, fen lisesi öğretmenlerinin, alanyazında yer alan önceki çalışmaların sonuçları ile benzerlik taşıyan sorunlarının (fiziksel şartlar, zamanlama, sınav sistemi vb.) var olması fen liselerindeki fen bilimleri dersleri ders saatlerinin yeniden gözden geçirilmesini gündeme getirmektedir. Örneğin 9. ve 10. sınıflar için haftada 2'şer saat olan kimya ders saatinin arttırılması, 3 ya da 4 saat olması önerilebilir. Çünkü, diğer liseler için geçerli olan 9. ve 10. sınıf öğretim programında yer alan temel düzey kimya ile hedeflenen 'genel kimya kültürü edinilmesi' fen liseleri için geçerli değildir. Fen lisesinde okuyan öğrenciler 'genel kimya kültürü edinme'nin ötesine geçmek için fen liselerini seçmişlerdir. Bu nedenle, kimya öğretim programının fen liseleri için yeniden yapılandırılması durumunda haftalık ders saati sayılarında da düzenleme yapılması önerilebilir. Böylece, öğrenciler için daha fazla deney, gözlem, model, uygulama yapabilecekleri, yapısalcı yaklaşımın yapısına daha uygun bir ögretim programı oluşturulabilir.

Bu çalışmada açık-uçlu anket ile veri toplanmış olup verilen cevaplar öğretmenlerin yazdıkları ile sınırlı kalmıştır. Daha kapsamlı ve derinlemesine veri toplanması için bireysel görüşmelerin yapılması önerilebilir. Çünkü bireysel görüşmelerde öğretmenler kendilerini daha rahat ifade edebilecekleri ve sorulacak olan sonda sorular ile daha detaylı bilgi elde edilebileceği düşünülmektedir. 


\section{Kaynaklar}

Açıkgöz, K. Ü. (2003). Aktif öğrenme. İzmir: Eğitim Dünyası Yayınları.

Ayas, A. (2013). Cumhuriyet döneminde Türkiye'de kimya öğretim programı geliştirme çalışmaları. M. Sözbilir (Ed.). Türkiye'de kimya eğitimi, Istanbul: Türkiye Kimya Derneği Yayınları.

Aydın, A. (2008). Ortaöğretim öğretmenlerinin 1992'den beri uygulanan ortaöğretim kimya müfredatları hakkındaki görüşleri. Eğitim ve Bilim, 33, 87-99.

Aydın, A. (2010). Cumhuriyet dönemi ortaöğretim kimya öğretim programlarının esnek program ve uygulamaları açısından değerlendirilmesi. Balıkesir Üniversitesi Fen Bilimleri Enstitüsü Dergisi, 12(2), 61-74.

Aykaç, N., Aydın, H., Gülbahar, Y., Özdemir, O., Menteşe, S., Eronat, A. ve Uzunca, Ş. (2006). Öğrenme-ögretme sürecinde planlama ve uygulama, Antalya: Naturel.

Binbaşığlu, C. (1988). Genel öğretim bilgisi, Ankara: Binbaşığlu Yayınevi.

Çalık, M. (2016). Turkey. B. Vlaardingerbroek ve N. Taylor (Ed). Teacher quality in upper secondary science education: International perspectives (s: 131-146). İngiltere: Palgrave Macmillan.

Demircioğlu, G., Aslan, A. ve Yadigaroğlu, M. (2015).Yenilenen kimya dersi öğretim programının öğretmen görüşleri ile destekli analizi. Ĕgitim ve Ögretim Araştırmalarl Dergisi, 4(1), 135-146.

Demirel, Ö. (1992). Türkiye'de program geliştirme uygulamaları. Hacettepe Üniversitesi Eğitim Fakültesi Dergisi, 7(7), 27-43.

Ekiz, D. (2004). Teacher professionalism and curriculum change: Primary school teachers' views of the new science curriculum. Kastamonu Eğitim Dergisi, 12(2), 339-350.

Elmas, R. (2016) How do we proceed? A needs assessment study with chemistry Teachers.International Conference New Perspectives in Science Education, Floransa, İtalya.

Elmas, R., Öztürk, N., Irmak, M. ve Cobern, W. W. (2014). An investigation of teacher response to national science curriculum reforms in Turkey. Eurasian Journal of Physics and Chemistry Education, 6(1), 2-33.

Ercan, O. (2011). Kimya dersi yeni öğretim programının uygulanmasına ilişkin öğretmen görüşleri. Türk Fen Eğitimi Dergisi, 8(4), 193-209.

Erdoğan, M. (2007). Yeni geliştirilen dördüncü ve beşinci sınıf fen ve teknoloji dersi öğretim programının analizi: Nitel bir çalışma. Türk Eğitim Bilimleri Dergisi, 5(2), 221-259.

Johnson, B. ve Christensen, L. (2014). Eğitim araştırmaları. nicel, nitel ve karma yaklaşımlar, (Çev. Editörü: Selçuk Beşir Demir), Ankara: Eğiten Kitap.

Mercan, F. Ç. (2014). 2007 Ortaöğretim kimya dersi öğretim programının içeriği ve kurgusuyla ilgili öğretmen görüşleri. Mehmet Akif Ersoy Üniversitesi Ĕ̌itim Fakültesi Dergisi, 30, 1 -22.

MEB (Millî Eğitim Bakanlığı Talim ve Terbiye Kurulu Başkanlığı). (2007). Ortaöğretim kimya dersi öğretim programı. T.C. Milli Eğitim Bakanlığı. Ankara. Erişim tarihi, 23 Nisan 2016, erişim adresi: 
http://ogm.meb.gov.tr/belgeler/kimya9.pdf

MEB (Millî Eğitim Bakanlığı Talim ve Terbiye Kurulu Başkanlığı).(2013).

Ortaöğretim kimya dersi (9-12. Sinıflar) öğretim programı. T.C. Milli Eğitim Bakanlığı. Ankara. Erişim tarihi, 23 Nisan 2016, erişim adresi:

http://ttkb.meb.gov.tr/program2.aspx/?width=900\&height=530\&TB iframe $=$ true

Özden, M. (2007). Kimya öğretmenlerinin kimya öğretiminde karşılaştıkları sorunların nitel ve nicel yönden değerlendirilmesi: Adıyaman ve Malatya illeri örneği. Pamukkale Üniversitesi Ĕgitim Fakültesi Dergisi, 22(2), 4053.

Patton, M. Q. (2002). Qualitative research \& evaluation methods ( $\left.{ }^{\mathrm{rd}} \mathrm{ed}.\right)$. California: Sage Publication

Pekdağ, B. ve Erol, H. (2013). 1957-2007 yılları arasında yayımlanan ortaöğretim kimya dersi öğretim programlarının gerekçe, amaç ve içerik yönünden incelenmesi. Kuram ve Uygulamada Eğitim Bilimleri, 13(1), 631-659.

Seçken, N. ve Kunduz, N. (2013). 9. Sınıf kimya dersi öğretim programlarının değerlendirilmesi. Hacettepe Üniversitesi Eğitim Fakültesi Dergisi, Özel Sayı (1), 344-358.

Ünal, S., Çoştu, B. ve Karataş, F. Ö. (2004). Türkiye de fen bilimleri eğitimi alanındaki program geliştirme çalışmalarına genel bir bakış. Gazi Eğitim Fakültesi Dergisi, 24(2), 183 - 202.

Turgut, M. F. (1990). Türkiye'de fen ve matematik programların yenileme çalışmaları. Hacettepe Üniversitesi Eğitim Fakültesi Dergisi. 5(5), 1-14.

Varış, F. (1996). Eğitimde program gelişstirme, Ankara: Alkım Yayıncılık.

Yıldırım, A. ve Şimşek, H. (2013). Sosyal bilimlerde nitel araştırma yöntemleri. İstanbul: Seçkin Yayıncılık. 


\section{Extended Summary}

\section{Purpose}

The chemistry curricula have been modified due to the changes in the field of chemistry, approach in education, and the nation's future goals. For a more effective chemistry education, it is important to consider the experiences and the views of the practitioner chemistry teachers. The purpose of this study was to investigate the views of chemistry teachers who were working at science high schools, about the chemistry curriculum which was revised in 2013 , and started to be implemented since 2013-2014 gradually.

\section{Method}

This study was designed as a survey study to elicitthe views of chemistry teachers working at science high schools, about the revised chemistry curriculum by giving an open-ended questionnaire.

The sample was selected through purposeful sampling, at which, first the science high schools located in seven geographical regions of Turkey, were determined, and then, through the convenience sampling representative schools were selected. The teachers were contacted personally by the researchers and the aim of the study was explained. Forty-two chemistry teachers working at science high schools participated voluntarily in the study. While eight teachers had master's degree two teachers had PhD. The majority of the teachers $(n=26)$ had more than 20 years of experience and 15 teachers had experience between 10-20 years, and only one teacher had experience of 0-10 years.

The views of the teachers were collected by an open-ended questionnaire, Chemistry Curriculum Evaluation Questionnaire (CCEQ), where they compare the current curriculum with the previous one. The CCEQ contained 5 main themes; namely, the structure of the curriculum, acceptance of curriculum, views about the content of the curriculum, feelings about the curriculum, and implementation of the curriculum. The data were analyzed by the content analysis; first all the data were open-coded, and then based on the themes existed in CCEQ, and categories and subcategories were determined by adopting a more deductive approach (Patton, 2002). During the coding, inter-rater reliability was established by having the two researchers code and reach full agreement.

\section{Results}

The responses of teachers were coded and categorized based on the existing themes in CCEQ.

I. The structure of the curriculum: The results of the analysis of data showed that the majority of the chemistry teachers reported that both teachers and 
the students were also active in the current curriculum. About the same percentage of teachers showed positive and negative views about the learning activities and the measurement and evaluation parts in the curriculum. The majority of the teachers $(n=31)$ reported that in this curriculum, they were more in an oral communication with their students therefore that affected their style of teaching. As an extension, again the majority of the teachers $(n=31)$ said positive views about the textbooks published for the current curriculum and 26 teachers conveyed positive thoughts about the supplementary materials aligned with the curriculum.

II. Acceptance of curriculum: All the teachers, with no exception, said they owned the curriculum booklet and they often used it when they prepare their lesson plans.

III. Views about the content of the curriculum: The majority of the teachers mentioned that the curriculum was clear and easy to understand. The teachers argued that some topics were given more intense in some years, especially in grade 9,11 and 12 . They mostly agreed that the topics in the $10^{\text {th }}$ grade were not difficult, but they leave room for memorization. In addition, the majority of the teachers $(n=26)$ reported that the topics in the curriculum were related to one another and with daily-life. All in all, they agreed $(n=36)$ that the topics in the curriculum are not difficult for the students studying at science high schools.

IV. Feelings about the curriculum: The majority of the teachers $(\mathrm{n}=26)$ mentioned about positive feeling while implementing the current curriculum. They listed the causes of their feelings as teaching to students, deepening content knowledge, curriculum itself, increasing professional experience and professional satisfaction

V. Implementation of the curriculum: The teachers also reported several factors, such as physical conditions $(n=11)$ students $(n=10)$ and planning $(n=5)$ as some of the factors affecting their implementation of the curriculum

\section{Discussion}

This study conveyed views chemistry teachers who were working at science high schools about the current chemistry curriculum. The majority of the chemistry teachers reported that both teachers and the students were also active in the current curriculum, and about the same percentage of teachers showed positive and negative views about the learning activities and the measurement and evaluation parts in the curriculum. In addition, the majority of the teachers mentioned that the curriculum was clear and easy to understand, yet some topics were given more intense; and students, physical conditions and planning were the factors affecting the implementation of the curriculum. 
$\underline{\text { S.Akaygün, R.Elmas.../ EÜ Ĕ̈̈itim Fakültesi Dergisi, 18-2 (2016),737-770 }}$

\section{Conclusion}

In conclusion, while the teachers were bringing some suggestions regarding the system, the content and structure of the curriculum, textbooks and other materials; they emphasized the differentiation of the curricula according to the school types. 